\title{
From the fuel versus food controversy to the institutional vacuum in biofuel policies: evidence from West African countries
}

\author{
Charly Gatete ${ }^{1,2}$ and Marie-Hélène Dabat ${ }^{2^{*}}$
}

\begin{abstract}
Background: Since the early 2000s, biofuel production has been developed in West Africa with the encouragement and support of notably Europe, Brazil, and China. Yet the development of biofuels can also be viewed from the angle of West African interests. The principle arguments advanced in favor of biofuels pointed to their potential to reduce oil trade deficits and improve the populations' access to ready, cheap energy. Biofuels consequently began to be put on the political agendas of West African countries.

Ten years after the first Jatropha plantations for energy use were established in West Africa, and in the light of the uneven development of the biofuel sector across the region, we analyze the factors that surprisingly led to policy inaction in many of these countries.

Methods: We used the concept of policy cycle stages to analyze the involvement of stakeholders in building biofuel policy and the factors behind incomplete public policies. The methods and tools that have been defined for the analysis of the relationships and interplay between actors are based on an analysis of the positions and interests of different stakeholders and on the comparison of their influence and importance in the design and implementation of projects, programs and policies. Our approach is inspired by the literature on Stakeholder Analysis, but also draws from the field of New Institutional Economics. We developed our own analytic framework (the "4C") which breaks down the interplay between different types of stakeholders and into four types of relationships: coordination, concertation, cooperation and contractualization. Our research process was based on a ranging study conducted between 2011 and 2014. Multilevel approaches were used to understand multi-scale and multi-sector biofuel issues. The analysis employed a large range of methods, including the reading of reports and political texts and conducting interviews. The documentary analysis helped to identify stakeholder groups for the stakeholder analysis. We then carried out interviews with a panel of stakeholders.

(Continued on next page)
\end{abstract}

\footnotetext{
* Correspondence: marie-helene.dabat@cirad.fr

${ }^{2}$ UMR Actors, Resources and Territories in Development (ART-Dev) - Centre

de coopération internationale en recherche agronomique pour le

développement (CIRAD), 73 rue Jean-François Breton, 34398, Montpellier

Cedex 5, France

Full list of author information is available at the end of the article
} 
(Continued from previous page)

Results: The study shows that it was the energy ministries of West African countries, encouraged by international cooperation agencies, which stepped forward to establish biofuel strategies, paying little attention to the issues at stake for agricultural producers or local communities. Around the same time, increases in food prices on the international market began to damage the image of biofuels, which came to be perceived as a threat to the food security of populations in developing countries. In several countries dependent on outside technical and financial support, this shift in the international discourse influenced the position of agriculture ministries, which became lukewarm or even opposed to biofuels. An outstanding result of the study is that the double talk at the international level_favorable and unfavorable to biofuels_-and power games inside the countries crippled the coordination of public action to support the sector, generated an institutional vacuum, led to conflicts between stakeholders, and hampered the sustainable development of biofuel projects and sectors in several West African countries.

In conclusion, we then emphasize the need to turn inaction into action: regulation frameworks must be implemented if the biofuel sector is to survive in West Africa.

Conclusions: The development of biofuels in the majority of West African countries suffers from an absence of a clear vision shared by all stakeholders and a lack of coordination between public actors. An institutional vacuum has taken hold which prevents investments in and the sustainable development of the biofuel sector and respectful of the interests of family farmers, who represent the majority of the population. The governments in these countries mainly worked through the ministries in charge of energy, which have become the leaders on the biofuel question. National biofuel policies are thus primarily focused on the energy potential of biofuels and on technical and economic dimensions of processing Jatropha seeds into oil and biodiesel rather than on upstream and downstream social objectives. If the biofuel sector is to survive in West African countries, the inaction of public actors has to be reversed by establishing the institutional frameworks needed to facilitate such development.

Keywords: Biofuels, Public policy, Strategy, Stakeholders, Partnership, West Africa, Burkina Faso

\section{Background}

Since the early 2000s, biofuel production has been developed in West Africa with the encouragement and support of notably Europe, Brazil, and China, each for their own reasons. Yet the development of biofuels can also be viewed from the angle of West African interests. Since the mid-2000s, West African countries have sought to develop biofuels based on Jatropha curcas plants. This production responds to several challenges: energy self-sufficiency, income and employment generation based on a new commercial crop, technological change, social advancement, rural development [1-3]. Negative social and environmental effects of this production (taking the place of staple food crops, pressure on arable land and natural resources) [4] have not been widely felt in the region. This is related to the recent drop in oil prices on international markets, which is undermining the viability of these projects and limiting the quantities produced [5].

A comparative analysis of biofuel development in West African countries reveals diverse national trajectories. However, a striking feature is that in many countries the development of biofuels has been hobbled by the absence of a clear and shared vision among stakeholders, in particular public actors, regarding the direction which should be given to this sector. Although national biofuel strategies have been formulated, they are not creating an institutional environment conducive to the stable development of this production. Ten years after the first Jatropha plantations for energy use were established in West Africa, and in the light of the uneven development of biofuels there, we reflect on the inaction of the governments of the countries in question, which have not implemented frameworks to regulate the development of the biofuel sector. These political actors have failed to adequately anticipate the possible consequences of the innovation which they promoted, assess the conditions of sustainability, or prepare to manage eventual risks.

This article seeks to explain how clashing stakeholders' strategies, against a backdrop of controversy over biofuels, led to situations where coordinated public action is now absent, conflicts rage, and the development of biofuels is blocked. The article examines the factors that led to policy inaction in four African countries and the need to turn inaction into action if the biofuel sector is to survive. The section which follows presents the analytical frameworks and methodology used. The third section of the article, in which the results are presented and discussed, is subdivided into three subsections. The first examines the development of the biofuel sector and the formulation of policies through the involvement of stakeholders. The second uses a specific framework to 
analyze the interplay of public and private actors. The third explores in greater depth the positions of the dominant actors as well as the conflicts between different actors, with a focus on Burkina Faso. The fourth section presents our conclusions.

\section{Analytical frameworks and methodology}

The study was carried out in West Africa. The literature review, as part of both a research program on the biofuel sector $^{1}$ in West Africa and an appraisal study of bioenergy policies in Central and West Africa, ${ }^{2}$ covered a large number of countries. We focus here on four: Benin, Senegal, Burkina Faso, and Mali. Biofuel development has only recently begun in Benin and Senegal. In contrast, the first bioenergy projects in Burkina Faso and Mali were launched in the 1980s and further projects were initiated in both countries in 2007.

\section{Analytical frameworks}

We used the concept of policy cycle stages [6] as the framework to analyze the involvement of stakeholders in building biofuel policy and the factors behind incomplete public policies. These stages are as follows: emergence and identification of a problem, agenda setting, policy formulation and adoption, implementation, evaluation, and termination. While this sequential vision has its limits, as several stages may overlap or be superimposed [7], this cycle seems appropriate when attempting to analyze and understand how public policy is formulated. The analytical breakdown renders it possible to isolate key moments in the policy making process and to concentrate on the interactions between various stakeholders at each stage.

Stakeholders' perceptions, roles, and responsibilities were identified in the study [8]. In keeping with [9], the relationships between stakeholders, as well as the identification of possibilities of synergy or occurrence of conflict between different groups, were brought to light.

For the analysis of the relationships and interplay between actors, we turned to the literature on stakeholder analysis (e.g., $[10,11])$. The methods and tools that have been defined there are based on an analysis of the positions and interests of different stakeholders and on the comparison of their influence and importance in the design and implementation of projects, programs, and policies. The Stakeholder Participation Matrix is a tool often used to measure the degree of involvement of actors and their interactions within a program or in the implementation of policy. In this matrix, the consultation or concertation and the collaboration or cooperation between stakeholders are significant factors in actor relationships which must be considered when performing a stakeholder analysis.

The extensive literature on stakeholder analysis is partitioned; some authors focus on concertation or participation [12-19], others on collaboration or cooperation between stakeholders [20-22] and yet others on the coordination of public actors' activities [23-28]. None analyze all of the relationship types together. Furthermore, consultation, cooperation, and coordination are usually analyzed as a relationship between private actors or between public actors. There also is no differentiation based on the nature of the actors. It would be difficult to use such an approach to analyze complex relationships such as those found in the biofuel sector, where many types of actors interact on several levels (local, national, and international).

We therefore developed our own analytic framework (the " $4 \mathrm{C}$ ") which breaks down the interplay between different types of stakeholders and into four types of relationships: coordination, concertation, cooperation, and contractualization. Our approach is inspired by the literature on Stakeholder Analysis, but also draws from the field of New Institutional Economics. It is similar to the method used by Ornston and al. [29] but offers the possibility of distinguishing relations according to the types of actors involved. Indeed, this framework specifies and finely explains interactions by groups of actors: between private actors, between public actors, between private and public actors, and between domestic and foreign actors. We then seek to estimate the strength of the partnerships between stakeholders and examine how this may explain the specific institutional configurations found in each country.

The first type of relationship in our framework is the "coordination" of public actors and activities. Public actors are involved in discussions concerning policy goals, objectives, design, and implementation. The consultation between several ministries in defining public policy is what Lascoumes and Le Gales [27] call the coordination of central governments or public coordination. In a sector such as biofuels, which may be a subject of interest for several ministries, this coordination is important in public policy construction [8].

"Concertation" between public and private actors is the second type of relationship, and the one studied most in stakeholder analyses. We examine how public and private actors interact in the development of the sector.

"Cooperation" between stakeholders, including national and international actors, is the third type. It is one of the main relationships studied in the context of stakeholder analysis, both with regard to the formulation of public policy [22] and the development of the biofuel sector $[20,30]$.

The fourth type of relationship, "contractualization", is important for the analysis of the coordination of private actors. In our approach, we use New Institutional Economics to assess coordination between stakeholders and specifically the way that relations between actors are institutionalized. 
The literature on the subject [31-34] have led to the definition of three modes of coordination: the market, vertical integration, and hybrid forms. The contract, or contractual relationships between private actors, is described as a major element in all three modes of actor coordination. Authors address the importance of contracting as a vertical mode of actor coordination in the agricultural sector and as a determinant of market efficiency [28, 35-38]. In line with these authors as well as $\mathrm{MME}^{3}{ }^{3} \mathrm{iE},{ }^{4}$ CIRAD $=$ Centre de coopération internationale en recherche agronomique pour le développement [39], $\operatorname{IOB}^{5}$ [40], $\operatorname{ADECIA}^{6}$ [41], and Gatete [8], we consider the contractual relationships between private actors as a relevant element for analysis of actor interplay within the biofuel sector.

Finally, we identified the main stakeholders in both the public and private sectors of the four countries studied. In the case of Burkina Faso, we identified some "key stakeholders". A key stakeholder is an intermediary [42], a political entrepreneur [43], or "passeur" [44], whose actions have very significantly shaped the emergence and development of biofuels. These specific stakeholders each occupy several spheres-private, political, technical and scientific-simultaneously.

\section{Methods}

Our research process was based on an exploratory and wide ranging study conducted between December 2011 and December 2014. Multilevel approaches were used to understand multi-scale and multi-sector biofuel issues. The multilevel analysis employed a large range of methods, including the reading of reports and political texts and conducting interviews, which were designed to unravel the complexities characterizing the conditions to which the biofuel sector and Jatropha activities are subject in these countries.

We used documentary analysis to review the main West African biofuel policies at national and regional levels. Special attention was given to the role of stakeholder interplay in the emergence and formulation of these policies, as well as gaps in their implementation. This analysis required the collection of considerable qualitative information which was made possible by reading many programs and policy documents related to the sector (official documents, scientific articles, policy briefs, etc.). This reading work was supplemented by interviews with private and public actors involved in the biofuel sector in the targeted countries.

For the stakeholder analysis, an initial documentary analysis helped identify stakeholder groups. It was complemented by field data obtained through interviews carried out with a panel of stakeholders. This panel was as comprehensive as possible, taking into account other stakeholders that the people interviewed thought we should meet to talk to. According to Reed et al. [45], stakeholders are all of the private and public groups, with a direct or indirect interest in the development of a resource (Jatropha in our case), that affect or are affected by decisions taken in the resource sector. Several groups of public stakeholders were interviewed: representatives of international organizations (CEDEAO, ${ }^{7}$ $\mathrm{UEMOA}^{8}{ }^{8}$ IUCN $^{9}$ ) and foreign agencies (French, Taiwanese, Dutch cooperation agencies), government officials (Ministry of Energy, Ministry of Agriculture, Ministry of Environment), researchers from national research institutes working on agriculture and environment, and private stakeholders (biofuel projects, farmer organizations). The data gathered enabled us to gain a deeper understanding of the emergence of biofuels at regional and national levels and the factors influencing biofuel policies and national strategy formulation.

Researchers interviewed 70 people (see Table 1 for the breakdown by country and group), recording a total of $186 \mathrm{~h}$. The interviews focused on the stakeholders' goals, strategies, and achievements, and their relationships with other actors. Structured questionnaires were used to capture the actors' discourses, perceptions, and actions, as well as the interplay between them. Speeches and representations were then analyzed to understand and compare interactions between actors that explain different biofuel development dynamics in the countries studied.

\section{Results and discussion}

The involvement of stakeholders in the emergence and building of biofuel policies in West African countries

Biofuel policies were developed in a multi-stakeholder context (public, private, local, national, foreign, international...) with the involvement of these actors fluctuating during different stages of the policy making process. An analysis of the emergence of the sector and the development of public policy reveals diverse sets of stakeholders.

Although a few bioenergy projects were implemented in West Africa in the 1980s, the sector really began to take off in 2005 with the sustained rise in oil prices, and experienced a boom when oil prices rocketed upwards in 2007-2008. Since that time, several initiatives have

\begin{tabular}{llllll} 
Table 1 Distribution of individuals interviewed per country & \multicolumn{1}{l}{$\begin{array}{l}\text { Representatives } \\
\text { of international } \\
\text { organizations } \\
\text { and foreign } \\
\text { agencies }\end{array}$} & $\begin{array}{l}\text { Government } \\
\text { officials }\end{array}$ & Researchers & $\begin{array}{l}\text { Private } \\
\text { stakeholders }\end{array}$ & Total \\
\hline Benin & 2 & 5 & 2 & 6 & 15 \\
Burkina & 4 & 8 & 2 & 15 & 29 \\
Faso & 2 & 6 & 1 & 5 & 14 \\
Mali & 2 & 5 & 2 & 4 & 12 \\
Senegal & 1 & 24 & 7 & 30 & 70 \\
Total & 9 & & & & \\
\hline
\end{tabular}


been launched in West African countries by foreign public funding agencies and private promoters, who are accompanied and supervised to varying degrees by policies and strategies formulated for the development of the sector.

We propose to use the policy cycle stages described by Muller [6] to analyze the interactions and level of involvement of stakeholders in building biofuel policies (Fig. 1).

We focus in particular on the first four stages: emergence and identification of a problem, agenda setting, policy formulation and adoption, and policy implementation.

\section{Emergence and identification of a problem}

The high cost of energy resulting from dwindling oil resources was the main factor behind rekindled ${ }^{10}$ global interest in biofuels in both the North and South. Biofuel production appeared to be an alternative solution to a societal problem of access to cheap energy. Against the backdrop of the oil crisis (with oil prices reaching US $\$ 140$ per barrel in June 2008), stark questions arose related to energy dependence, availability of fuel for consumers, and trade balances. The high cost of oil motivated industrial countries to stimulate the production of biodiesel and bioethanol, particularly for use in the transportation industry.

In West Africa, biofuel production has been developed with the encouragement and support of notably Europe, Brazil, and China. The motivations underlying their promotion of biofuel production in Africa are quite different: European countries are looking for raw material to import for biodiesel production; Brazil is striving to transfer technologies to African countries, especially ones relating to bioethanol; and China is seeking to maintain control over foreign sources of biofuel which are supplying its national market by supervising the development of industrial bioethanol and biodiesel production in the countries of origin (Fig. 2).

However, the development of biofuels can also be viewed from the angle of developing countries' interests. Some West African countries saw biofuels as an opportunity to both reduce energy dependence and boost their economic development [46-51]. These countries are experiencing high population growth rates and lack nonligneous energy resources, rendering them heavily dependent on hydrocarbon imports. High international oil prices in the mid-2000s sparked interest in biofuels, which appeared to offer an innovative solution to this problem.

Thus at both the international level as well as that of the West African states, the principle arguments advanced in favor of biofuels pointed first to their potential to improve the populations' access to ready, cheap energy, and second to their potential contribution to agricultural development.

\section{Political agenda setting}

In West Africa, the sector has been developed and policies formulated via numerous, direct, private initiatives at the national level, and under the impetus of public actors at the regional level (Fig. 2).

The first initiatives were made by foreign or national promoters to increase production of oilseed plants (mainly Jatropha) and sugar crops (sugar cane) on African land, with the support of the governments of sub-Saharan countries, and export this production to European, American, and Asian markets. A "land rush" followed in sub-Saharan Africa [52] motivated by a quest to incorporate biofuels with other energy sources defined in the USA and Europe. For instance, to increase the supply of biofuels and better respond to national European markets, Directive 2003/30/EC on the promotion of biofuels encouraged European promoters (NGOs and multinationals) to launch several biofuel projects in Africa $\mathrm{CEA}^{11}$ [53]. These initiatives sought to cultivate Jatropha with the idea of exporting the seeds to Europe where they would be transformed into biodiesel.

In parallel with these private initiatives, public sector actors, mainly from Europe ${ }^{12}$ (the European Commission through the European Development Fund, Dutch and German cooperation agencies) but also Brazil, alongside several regional organizations, also became involved. They influenced the initiatives of West African

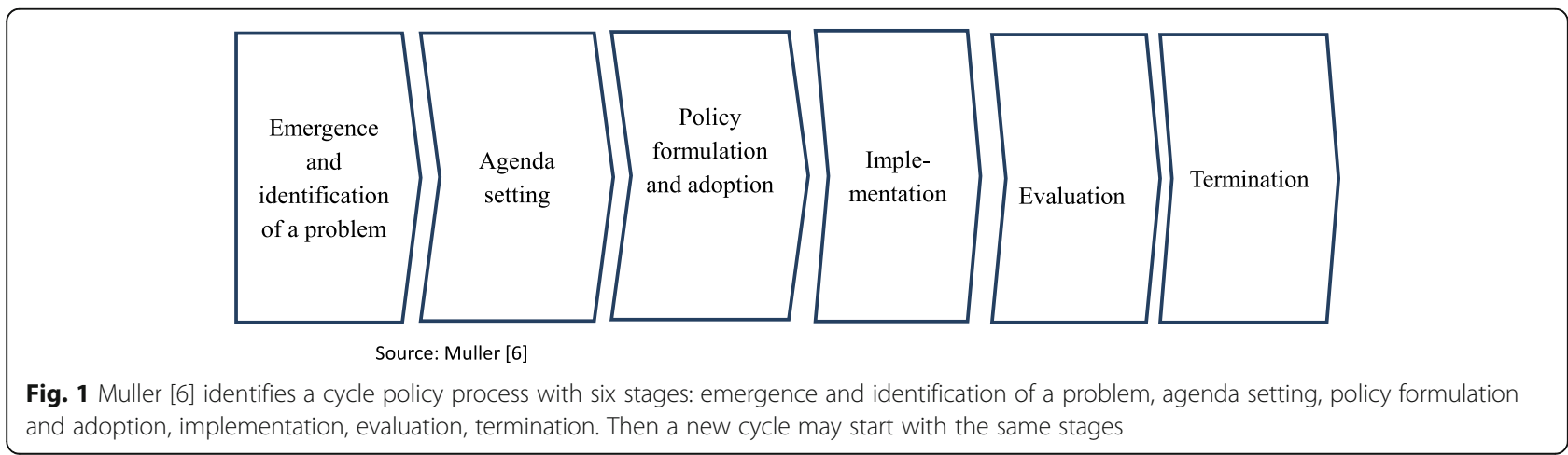




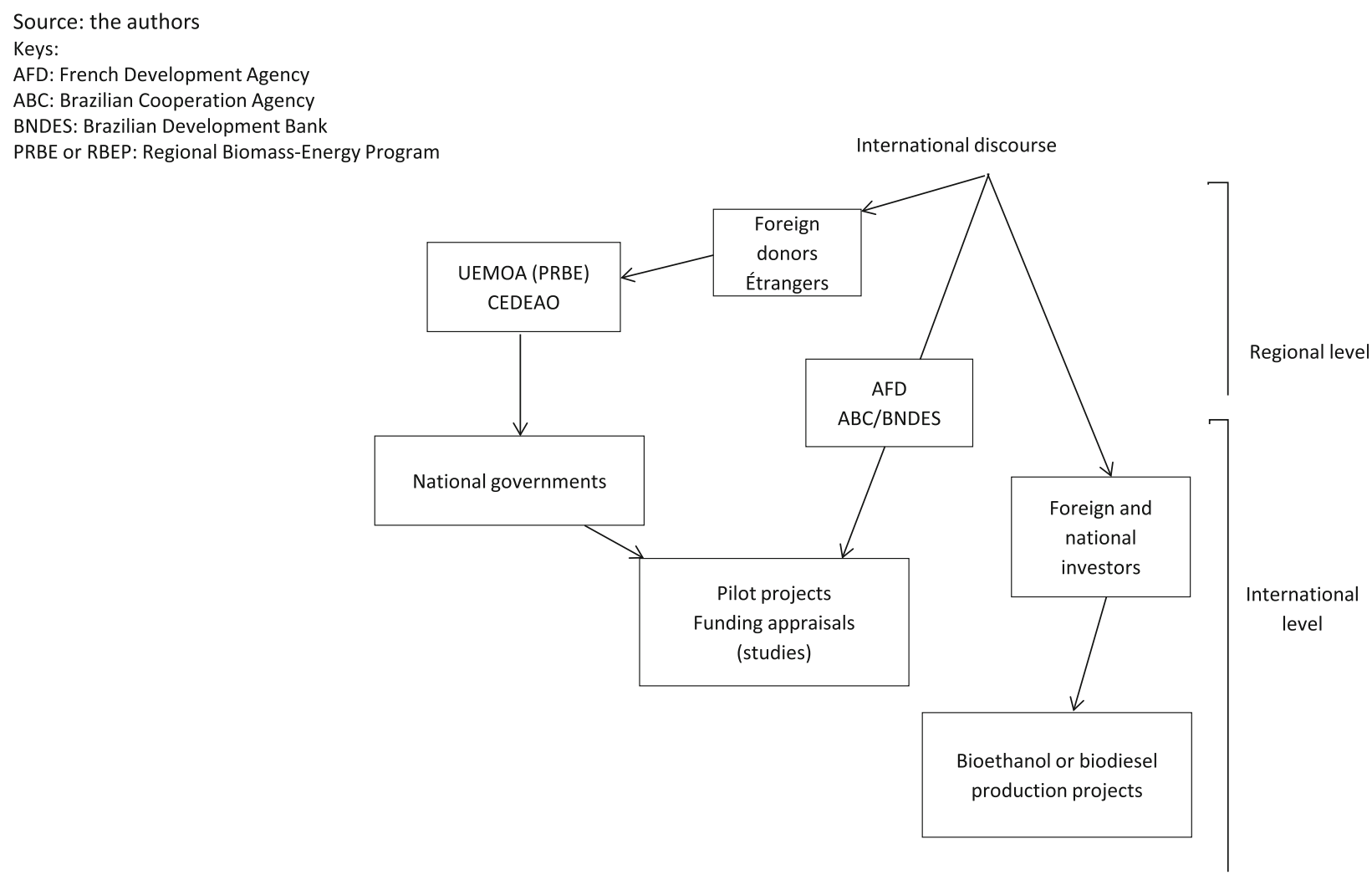

Fig. 2 There are several pathways of emergence and entry of biofuels onto national agendas with different motivations underlying their promotion. European countries, Brazil, and China do not pursue the same objectives but they are all interested in supporting biofuel activities in Africa

actors by funding pilot projects aiming to satisfy both international and domestic markets, research programs, and meetings between decision makers (UEMOA/ CEDEAO Summit in 2006, Brazil organized study trips to the country for UEMOA officials and representatives of farmer organizations).

The involvement of national public actors was due to impetus at the regional level, with UEMOA playing a leading role in attracting funding and transferring ideas. It was the main interface used by foreign donors to fund regional and national biofuel projects and programs. The Regional Biomass-Energy Program (RBEP), launched in 2004 with Dutch funding ( $€ 2.5$ million) and composed of two 3-year phases, is a reflection of the strong regional political will to promote biomass-energy [54]. The program financed studies ${ }^{13}$ and expert assessments to develop national strategy documents, but did not have the resources to implement significant actions within the countries. With regard to Brazil, UEMOA sought to capture funding for the implementation of regional and national biofuel initiatives based on the Brazilian model of the sector by signing a memorandum of understanding with the country in 2007. This reflected the leading role Brazil wished to play in this field in West Africa. However, 8 years later, few concrete actions have been implemented, and only a few feasibility studies have been launched with funding from the Brazilian Cooperation Agency (ABC) and the Brazilian Development Bank (BNDES). Some studies, which are less well known and harder to access, have apparently been financed by private Brazilian industries.

The combination of these initiatives by public and private, national and international actors, influenced by international discourse regarding biofuels, shaped the manner by which the political agenda was set in each country. In Benin, the question emerged fairly rapidly under the impetus of the country's president following his visit to Brazil in 2007. The government then initiated and supported the establishment of a protocol of understanding between the two countries [55] and the setting up of a committee to monitor the implementation of biofuel initiatives.

In Burkina Faso, the issue emerged gradually and took several forms under the influence of three key individuals: a technical adviser who influenced the Ministry of Energy, a research scientist who studied Jatropha during the 1980s, and a highly influential politician/traditional chief with extensive political and media contacts who promoted Jatropha-based biofuels and invested in the sector on his own behalf (see below). 
In Mali, the emergence process was similar to that of Burkina Faso with the involvement of a large number of actors: NGOs, multinationals, cooperation agencies (SNV and $\mathrm{GTZ}^{14}$ which launched a bioenergy project in the 1980s).

In Senegal, emergence was gradual and driven, as in Benin, by the country's president following the reciprocal visits of the Brazilian President to Senegal in 2005 and the Senegalese President to Brazil in 2007. These visits reinforced the determination of the government, which created the Ministry of Biofuels in 2007 [56].

\section{Policy formulation and adoption}

The emergence of biofuels in the political sphere led to the production of a certain number of policy documents which involved public sector actors in different ways (Table 2). In Benin and Burkina Faso, only framework documents outlining the vision and strategy exist. Benin developed a "Strategy for the Promotion of the Biofuel Sector" following a relatively long process begun in 2006 under the coordination of the Ministry of Energy which mobilized to a lesser degree the Ministry of Agriculture, the Ministry of Trade, the office of the President, the oil industry, and diverse consultants. This text was finally adopted by the government in 2011. In Burkina Faso, the strategy developed by the Ministry of Energy in 2009, named the "Framework Document for Biofuels Promotion Policy" [57], has not yet been adopted by the government.

In Mali and Senegal, the political and regulatory framework is slightly more developed. In Mali, the "National Strategy for Biofuel Development" was adopted by the government in 2008 (Gouvernement du Mali 2008 [58]) and the regulatory framework drafted in 2011 is pending adoption (Gouvernement du Mali 2011 [59]). Both documents were drawn up under the coordination of the Ministry of Energy with contributions from other actors (see below). In Senegal, the biofuels law adopted by the government and National Assembly in 2010, and the regulatory framework drafted in 2012 and still pending adoption, were both drawn up by the Ministry of Biofuels.

\section{Policy implementation}

The implementation of these biofuel policies has been limited due to evolutions in both petroleum prices and the international debate on biofuels. Following sharp increases in agricultural product prices on international markets beginning in 2008, voices accusing biofuels of affecting food prices (food riots), land grabbing, and ultimately food security in poor countries have become louder [52]. Two opposing views of biofuels have emerged, with supporters, who view biofuels as a source of development based on better access to energy, pitted against critics, who point to the numerous risks posed by biofuels for local populations.

This evolution of the international debate influenced the position, by then lukewarm or even opposed to biofuels, of the ministries of agriculture in several countries. It also led numerous export projects to abandon or lower their objectives. Senegal changed its strategy, which initially was oriented around seed exports, to focus on production for the national market. In Benin and Burkina Faso, all public initiatives to facilitate the structuring of the sector by defining an incentive-based regulatory framework appear to be frozen. In contrast, the policy implementation process in Mali was more effective due to the activities of the Agence Nationale de Développement des Biocarburants (ANADEB, the national biofuels development agency), created in 2009.

One decade after the emergence of biofuels in these four countries, the biofuel sector, like elsewhere in Africa, is developing in an uncertain environment [60]. ${ }^{15}$ Public initiatives abound, but many policy documents are waiting to be adopted or implemented. Programs are at times suspended, their goals unclear. There thus is a marked discrepancy between stated goals (Table 2) and the resources actually employed. Regulatory frameworks are rarely complete and the different measures considered to be critical by stakeholders in the sector are on hold, leading to a true institutional vacuum. However, a regulatory framework to promote both the production and use of biofuels (incentives, information to users, etc.) is desperately needed. This need is felt particularly strongly with regard to the choice of where to locate crops, land access and use, support for investment, setting up and monitoring product standards, and price controls, among other issues. One example is the possible harm that could be caused by the lack of quality control regulations for Jatropha oil available on the market, and the absence of communication on its compatibility with the diesel engines in circulation ${ }^{16}$ (equipment breaking down, image of the new fuel diminished in the eyes of users, refusal to use it, etc.). This institutional vacuum leads to ambiguity which penalizes the development of the biofuel sector in these countries.

In most of the countries studied, private stakeholders blame politicians for the absence of a regulatory, legislative, and financial incentive framework supporting the development of biofuels. Only Mali seems to have become engaged in the development of a real institutional framework, the establishment of regulatory and fiscal tools, and the implementation of a strategy document. The failure to develop a policy and institutional framework appears to be the main obstacle impeding the development of the sector.

In the absence of government support, the promotion of biofuels relies on the activities of private operators 


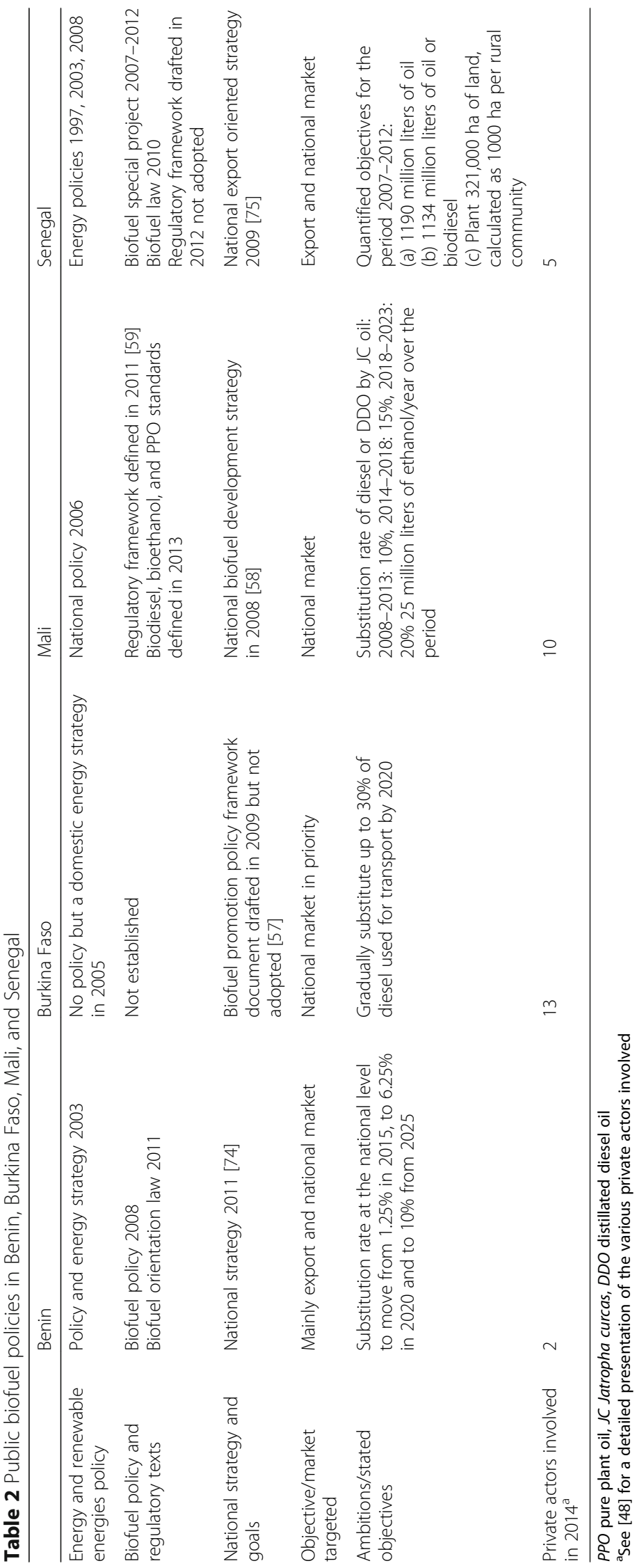


and the partnerships which they are able to develop between each other, whether with private foreign firms (mainly Chinese and Italian) or with NGOs. Due to the controversy over biofuels and the weak involvement of public actors, private promoters have in effect assumed almost entirely the risks related to biofuel production.

However, the countries have tried to build publicprivate partnerships as a means to develop confidence between multiple stakeholders involved with biofuels, overcome various challenges faced by the sector, develop collective responsibility, and share risks. While such a partnership appears to be operational in Mali under the impetus of ANADEB, it is not always easy to build in countries where political leaders are unsuccessful in generating private initiatives (for example, Senegal), or in countries where private operators lack government support (for example, Burkina Faso).

The nature of the actors involved in the sector but also the types of relationships between them has shaped the biofuel trajectory in each of the four countries. These countries were chosen due to the interest donors have taken in them, as well as to understand how countries which at one time shared a fairly similar vision (pro biofuel rhetoric particularly in Senegal, Benin, and Mali) could follow such different biofuel development trajectories.

\section{Use of the " $4 C$ " approach to analyze the relationships between stakeholders}

The level of involvement and the interactions of public and private stakeholders differ from country to country, and this influences the policy development and sector building processes in each. The following analysis enables the interactions between stakeholders in each country to be mapped out and compared. Partnerships between stakeholders appear to offer the advantage of conciliating the interests of most of the stakeholders involved. We seek to estimate the strength of the partnerships between stakeholders and examine how this may explain the institutional configuration in each country. To this end, we developed an analytic framework (the " 4 C") which breaks down the interplay between stakeholders into four types of relationships: coordination, concertation, cooperation, and contractualization.

\section{"Coordination" of public action}

We identified coordination between public actors (central government, territorial authorities...) as the first important relationship between stakeholders.

The importance of this relationship has been demonstrated by numerous authors $[23-25,27,28,61]$ and was defined as the preferred mode of action in the governance of the bioenergy sector in France [26]. The coordination of public action is essential when a multi- sectoral issue like that of biofuels is involved. It appears to be a prerequisite for the establishment of sustainable value chains responding to several sectoral interests.

The coordination of public action varied across the countries studied. In Mali, it was present from the very beginning and facilitated the definition of the national strategy in 2008 before ANADEB had even been established. In Senegal, it initially was formalized with the creation of a short life ministry in charge of biofuels composed of officials drawn from other ministries. Since the biofuel portfolio was placed under the Ministry of Energy and Renewable Energy Development in 2012, no visible joint ministry action has been taken. The situations in Benin and Burkina Faso also are characterized by weak coordination between public actors, notably between the actions of the Ministries of Energy and the Ministries of Agriculture. In each of these two countries, it is difficult to arbitrate between the Ministry of Energy's focus on energy access and the Ministry of Agriculture's concern for food security. In Benin, this situation led to a divisive debate between the two ministries over granting approval to a Chinese multinational seeking to produce bioethanol from cassava (see below).

The lack of coordination in the political sphere in each country aside from Mali, and the tension over the orientation to be given to the sector in the three other countries, is reducing the influence and capacity of public sector actors to build a policy, regulatory, and incentive framework. This situation thus hinders the construction of an institutional landscape conducive to the development of the sector.

\section{"Concertation" between public and private partners}

This is the second relationship to prioritize in each country. Several authors $[12-19,38,62]$ have shown that concertation is required to improve the management of agricultural development. Corral et al. [63] and Schut et al. [64] demonstrated that it facilitated biofuel production in Fuerteventura and Mozambique, respectively. It can be developed through exchange platforms, agencies, or units dedicated to biofuels as long as these are operational. Such platforms were set up in all four countries with varying degrees of influence in each. In Benin, the Commission nationale de promotion des biocarburants (CNPB, the national commission for promoting biofuels) was created in 2008; in Burkina Faso, the Comité interministériel chargé de la coordination des activités de développement des filières biocarburants (CICAFIB, an interministerial committee responsible for the development of the biofuel sector) also was created in 2008; in Mali, the ANADEB was set up in 2009, followed by the Commission nationale biocarburant (CNB, the national biofuels commission) in 2011; and finally in Senegal, the Comité national des biocarburants (CNB, a national 
biofuels committee) was created in 2010 . However, these platforms for concerted action have barely functioned and have not yet managed to connect essential public and private partners, nor have they facilitated the exchanges required for the definition of a biofuel policy and the structuring of the sector. In Burkina Faso, the CICAFIB has only met five times between 2008 and 2014. No activity has been developed by either CNPB in Benin or CNB in Senegal. Only ANADEB has been able to play an effective role by holding regular meetings between public and private actors and farmers. Depending on a given subject, ANADEB brings together government technical services, local authorities (named Cercles), project promoters of different sizes, producer organizations (notably $\mathrm{CNOP}^{17}$ ), the University of Bamako, research institutions such as IER ${ }^{18}$ professional training schools, laboratories, and consumer associations. ANADEB is a forum for exchange where experience and expertise on biofuels is gradually being forged. One example of its effectiveness is the publication of biofuels standards in 2013 [65]. ANADEB facilitated the structuring of the sector by establishing a multistakeholder and multi-sectoral partnership which renders it possible to conciliate the interests and visions of different stakeholders in order to build a more integrated sector which responds to the needs of the majority of the actors involved.

\section{"Cooperation" between foreign actors and national public and private actors}

This is the third important relationship that we identified. Bilateral and multilateral cooperation allows investments to be channeled towards the development of the sector $[20,21,66]$. Cooperation can take several forms, such as carbon finance activities or rural development support.

In terms of multinational cooperation, the Jatropha programs initiated by UNDP in Burkina Faso and Mali promote the use of vegetable oil in a network of multifunctional platforms. ${ }^{19}$ The World Bank, through its Program For Scaling Up Renewable Energy in Mali, which was launched in 2010 and includes a biomass component, funds initiatives related to decentralized rural electrification (DRE), environmental protection, and the mitigation of greenhouse gas emissions. The European Union (EU) first funded pilot production projects in Senegal, Mali, and Burkina Faso through the RBEP (see above), then the 2iE/EIFER ${ }^{20} /$ CIRAD "Valorisation énergétique de la biomasse en Afrique de l'Ouest'(Development of biomass energy in West Africa) research program.

Bilateral cooperation has taken place at various levels and in different forms. The Brazilian strategy consisted of channeling funds through the Brazilian Cooperation
Agency $(\mathrm{ABC})$ and the Brazilian Development Bank (BNDES) for many studies and assessments of the feasibility of biofuel sectors in numerous UEMOA countries (see above). Cooperation also can take the form of technology transfers such as Taiwan's funding of Jatropha seed crushing and processing equipment for three promoters $^{21}$ in Burkina Faso in 2012 (through the International Cooperation and Development Fund). Another means of action was to facilitate the installation of multinationals in these countries through public cooperation agencies which negotiate with national authorities. This was the case in Benin, where the Chinese state enterprise Complant (China National Complete Plant Import \& Export Corporation) acquired the sugar company Savé and supported the installation of the multinational company, Zheng Da Investments Limited, which hopes to obtain land to produce cassava-based bioethanol. Cooperation agencies also can become involved by directly providing loans to finance the industrial investment plans of private actors. This was the case, for example, of the French Development Agency (AFD), which awarded a loan to an industrial actor in Mali (Jatropha Mali initiative) in 2011. The German (GIZ, formerly GTZ) and Dutch (SNV) cooperation agencies also contributed to developing the sector by funding local efforts to produce oil for socio-economic activities and decentralized rural electrification (DRE) units. We should note that the German cooperation agency was the first to fund renewable energy and biofuel (PPO) development projects in Mali and Burkina Faso in the 1980s [8].

While it may seem simplistic to present complex institutional situations using the " $4 \mathrm{C}$ " framework, the tool allows an examination of the fulfillment or the failure of four types of relationships which we believe to be decisive in setting up sustainable sectors.

\section{"Contractualization" between private actors in the sector}

The coordination of activities between stakeholders operating at different points along a value chain also seems important to consider. Several authors [35-38, 67, 68] have shown the benefits of contractualization as a means to vertically coordinate actors in the agriculture sector and as a component of efficiency in market development. With regard to supplying the biofuel sector, Bamière et al. [69] and Hanff et al. [70] have highlighted that the contractualization of relations between farmers and project promoters is a prerequisite for ensuring the sustainability of supply while preserving family agriculture. Contractualization mainly was established in the countries studied by the promoters of projects involving the industrial production of oil or biodiesel using Jatropha, which requires vast quantities of seeds for the processing units to function. To ensure supplies, project promoters established Jatropha seed purchase contracts 
with farmer organizations. In contrast, the strategy followed by promoters of bioethanol production projects, notably in Benin and Senegal, was to produce sugar cane themselves on their own fields.

\section{Responsibility of public actors in the weak and risky development of biofuels}

The coordination of public actions is indispensable for public policy processes and national governance [28]. Public actors are in charge of ensuring this coordination, which furthermore conditions other relationships because coordinated state action provides governments with the means to incite and involve other actors [6]. In terms of the multi-sectoral specificity of biofuels, coordination is particularly critical when several government ministries are arguing over which one should assume leadership on the issue. To better understand the issues at stake in the coordination of public action, in the next two subsections we analyze the plays for influence and jostling for leadership on the biofuel question between energy and agriculture ministries. We then look at the special features of the Burkina Faso case to probe more deeply into the causes and consequences of the power games between these two players. We find that the evolution of the international debate on biofuels had an important influence on the positions taken by actors, the emergence of divisive situations, and the malfunctioning of the sector. Some internal power struggles also were behind the lack of incentives and weak coordination of public actions.

The leadership of the ministries of energy in most countries In the public decision making ring, each ministry seeks to promote its own sectoral interests within power struggles for leadership. The outcome of the confrontation of various ministries' views and discourses helps build a sector's policy and institutional framework and influences the orientations and choices of different stakeholders in the sector.

Encouraged by the international discourse and foreign aid agencies, it was fairly logical that the ministries of energy stepped forward to implement biofuel strategies without any real consideration of the issues at stake for agricultural producers or local communities. Biofuelrelated policies largely focused on the technical and economic aspects of biomass-based energy production without taking into consideration socio-economic objectives linked to agricultural production [70], and without paying much attention to the sustainable integration of energy crops into farming systems. In the four countries studied, one can see that the ministries in charge of energy are imposing their views of the development of the sector to the detriment of the views of the ministries of agriculture, which represent the interests of agricultural producers. Indeed, the biofuel policies which have been implemented unanimously focus on improving the access of populations (in particular rural) to energy in order to drive development, in contrast with the objectives governing these policies elsewhere in the world. ${ }^{22}$ The political arguments which have prevailed do not focus on stimulating a production or an agricultural sector by ensuring an outlet, but rather on developing energy services by supplying the necessary raw materials. The approach based on a finished product (PPO, bioethanol or diesel) for rural energy services has enabled energy ministries to position themselves as leaders on the question and to impose their views within their governments with a somewhat muted involvement of other ministries, notably agriculture. The treatment of the question from the sole perspective of energy, despite the multi-sectoral nature of biofuels, has thus led in some countries to a low level of involvement of other public actors, who found themselves marginalized. However, even though the international discourse focused greatly on the energy dimension, it was the responsibility of national public actors to broaden the treatment of the question to consider environmental, social, agricultural, and, more globally, rural development aspects. In effect, anchoring the issue within the field of rural development, which already was the subject of numerous policy documents (for example, the Rural Development Strategy in Burkina Faso), could have facilitated the establishment of relationships between numerous ministries, notably those of agriculture, energy, territory, and the environment.

With the exception of Mali, where the Ministry of Agriculture has played a major decision making role through its decentralized structures (notably the choice of Jatropha based on information provided by agricultural research and the choice of short marketing chains), the agriculture ministries in Benin, Burkina Faso, and Senegal have assumed much lower profiles. In Benin, the Ministry of Agriculture showed little interest in promoting biofuels during the development of the biofuel promotion strategy and dedicated little resources to it; biofuel plants are not, for example, listed among the 13 priority areas in the strategic plan for the revival of the agricultural sector (PSRSA) developed by the ministry in 2011. In contrast, in Senegal the Jatropha and sugar cane sectors were defined as such promising sectors in the Agro-Sylvo-Pastoral Act (LOASP) of June 2004 that a special Jatropha program was begun by the Ministry of Agriculture. However, today the Ministry of Energy is in control of the biofuel sector. In Burkina Faso, the weak to nonexistent involvement of the Ministry of Agriculture has been a major obstacle impeding the development of the sector (see below).

In the four countries, the energy ministries were the ones steering the development of policy and strategy documents 
on the promotion of biofuels. Furthermore, the fact that the various national biofuel agencies and committees are under the energy ministries does not facilitate public coordination (see above). While these concertation structures include representatives of several ministries (often those of agriculture, the environment, industry, research, and the economy), these other ministries play much less active roles in the implementation of biofuel policies and strategies. Without real operational autonomy (with the exception of ANADEB in Mali), these structures are barely functional and are unable to establish a framework of concerted action between the different ministries involved. Policies and strategies demonstrate a clear intention to involve a large number of public bodies, but their roles are not well defined, which renders policy implementation difficult.

\section{Illustration of power struggles and conflicts in the case of Burkina Faso}

Within the public decision making sphere, without effective upstream coordination of public action, conflicts can emerge and block the development of the sector, in particular when the biofuel agencies or committees are unable to ensure concertation between various sector stakeholders to develop and implement public policy. In particular, conflicts can emerge when public actors cannot ensure a regulatory and institutional framework adapted to the situation.

The case of Burkina Faso illustrates several types of conflicts. The Ministry of Agriculture remained quite remote from the development process of the sector. According to public administration theory [68], this situation could be understood as an expression of a conflict of views and interests, and of competition between ministries which has not been resolved. The Ministry of Energy is focused on energy issues (access to energy, reduction in the cost of hydrocarbon imports). Meanwhile, the Ministry of Agriculture, which oversees agricultural and rural development, is concerned about the food security of family farmers and land risks, echoing the international discourse [66].

Another facet of the Burkina Faso case is a personal conflict between a former Minister of Agriculture and a political go-between, Larlé Naaba. We became aware of this conflict during interviews conducted in May 2013 with these two people. Larlé Naaba, who is a key player in the sector, is widely known due to his title of traditional chief. He is furthermore a deputy in the National Assembly and an economic operator. In 2006, he began a joint venture biofuel production project named "Belwetbiocarburant S.A.". Due to his celebrity, his activities to promote Jatropha farming received considerable media attention, to the point that this political entrepreneur or "passeur" became known as "Mr. Jatropha" in Burkina Faso [71]. Following a visit to Larlé Naaba's home province, and on the occasion of a national day to promote Jatropha organized by Larlé Naaba in 2008, the then Minister of Agriculture entered into direct conflict with the traditional chief and publically stated his personal opposition to the promotion of Jatropha, which in his view would threaten food security. Larlé Naaba then used his political network to meet with highly placed government officials to obtain their support and assurances, and to continue his Jatropha production project. In December 2008, he could claim to have received a letter of encouragement from the President of the Republic. His prominent position enabled him to escort numerous national and foreign figures on visits to his experimental field and to obtain bank credit to finance his project and, more importantly, support and promote Jatropha farming in rural areas (seed donations, awareness-raising campaigns, local and national media coverage). The minister criticized the traditional chief for using his prominent, highly publicized, and influential position, for relying on arguments based mainly on energy independence, and the quasi unilateral development of biofuels by the Ministry of Energy. Meanwhile, the traditional chief reproached the minister for his "authoritarian" and personal management of the issue and the minimal involvement of his ministry. This situation contributed to blocking the biofuel dossier at the level of the Ministry of Agriculture and explains in part the ministry's limited involvement in the building of the policy and regulatory framework for the sector. The minister's political weight (he was minister several times) explains his capacity to block the dossier from advancing on the government's agenda. A lack of conclusive scientific research on the effects of biofuels on food security, and above all the controversy over the impacts of biofuels which emerged in 2005, reinforced his position and that of his ministry. ${ }^{23}$ However, since being out of office, the former minister and current deputy has confided that, with the benefit of hindsight, he is personally in favor of Jatropha farming, but only on arid land, and of the promotion of industrial value chains, which are the only ones he believes are likely to have a satisfactory impact on macroeconomic indicators. Nonetheless, the current Minister of Agriculture has stated a clear intention to ensure food security and does not appear to have changed the ministry's position.

This case of ideological conflict between the two ministries resulted from a collision between the interests of private actors guided by a desire for profitable projects, and the interests of public actors who wished to take advantage of the opportunities presented by biofuels and, sometimes, to minimize the risks linked to their production. Given the absence of a coordinated public policy, it is fortunate that biofuel production has caused few negative social and environmental effects (replacement of 
food crops, pressure on arable land and natural resources, etc.) in West Africa. The effects have been limited because production has remained low following the recent fall of oil prices on international markets, which has sapped the profitability of projects.

However, one may wonder in hindsight if the strategies and policies implemented adequately considered the risks involved and whether policy makers and donors adopted a responsible approach. Farmers, economic operators and rural families were pointed down a road which now appears to be a dead end. Farmers have been able to turn easily away from Jatropha, in which they did not have much invested. Rural populations in West Africa were not victims of land grabbing like in other countries, but the damage could have been more important. Economic operators (NGOs, associations, municipalities, small investors, etc.) were the real losers because they were squeezed between the need to pay attractive seed prices to encourage farmers and the need to produce vegetable oil and biodiesel at a price competitive with diesel. They also had to face relatively high seed collection costs, a result of sparse and scattered production, while bearing investment costs which they struggled to make profitable.

\section{Conclusions}

The process by which biofuels emerged in the countries studied followed several paths, steered by the international discourse on biofuels, fluctuating oil prices, the vision of different actors, and a backdrop of power struggles. No public biofuel policy, meaning an ensemble of coordinated actions implemented with the objective of obtaining a change in, or an evolution of, a given situation, exists today. This is what we have called a political and institutional vacuum. The governments of the countries registered biofuel investments without having any policy, legal or institutional framework to monitor them. The development of biofuels in Benin, Burkina Faso, and Senegal suffers in particular from an absence of a clear vision shared by all stakeholders and a lack of coordination between public actors. Public authorities were unable to develop biofuel strategies through a participatory process which could have led to an institutional environment both favorable to the sustainable development of the biofuel sector and respectful of the interests of family farmers, who represent the majority of the population in West African countries.

Our analysis of the relationships between stakeholders using the " $4 \mathrm{C}$ " framework presents complex relationships and varying degrees of stakeholder involvement depending on the country in question. While concerted action has overall been very limited, it is taking place in Mali with an integrated process associating numerous sector stakeholders. However, one hesitates to speak of a success story in this country when numerous challenges still need to be addressed (plant agronomy, competitiveness and organization of value chains, replacement of traditional fuels by biofuels, etc.) before production can reach the level needed for biofuels to assume a significant role in the national energy supply. In the other three countries, the national agencies and committees responsible for setting up frameworks for concerted action involving multiple actors to develop biofuel policies and the structuring of the sector have functioned poorly. An institutional vacuum has taken hold which prevents investments in and the sustainable development of the biofuel sector.

Although public coordination appears to be a key step in the development of the sector, the governments in these countries mainly worked through the ministries in charge of energy, which have become the leaders on the biofuel question. Other ministries, such as those of agriculture, or, to a lesser degree, the environment, economy and finance, and trade and industry, have exercised little influence over the orientation and implementation of policies and strategies. National biofuel policies are thus primarily focused on the energy potential of biofuels and on technical and economic dimensions of processing Jatropha seeds into oil and biodiesel rather than on upstream and downstream social objectives. In Burkina Faso, controversy over food security risks and personal tensions and differences influenced the position of some key players, blocking all possibility of public coordination and the establishment of a favorable environment for the sector. Yet, the question of the role of energy in rural development $[72,73]$ could have been the focus of coordinated, multi-sectoral public action.

In sum, there are sound reasons to highlight the inaction of public actors whose political choices (strategy, public policy) fluctuated according to the nature of the international discourse on biofuels, the solicitation of foreign donors, and changes in oil prices. Efforts have not been made to anticipate the risks of undesirable impacts or create conditions for the sustainable development of this production. If the biofuel sector is to survive in West African countries, this inaction has to be reversed by establishing the institutional frameworks needed to facilitate such development.

\section{Endnotes}

${ }^{1}$ Research conducted by $2 \mathrm{iE}$ and CIRAD and supported by the European Union (2010-2014).

${ }^{2}$ Appraisal study performed by CIRAD for IRAM (French studies center) and the Hub Rural and supported by the European Union (2014).

${ }^{3}$ Mining and Energy Ministry.

${ }^{4}$ International Institute for Water and Environmental Engineering. 
${ }^{5}$ Institute of Development Policy and Management.

${ }^{6}$ Agence pour le développement de la coopération internationale dans les domaines de l'agriculture, de l'alimentation et des espaces ruraux.

${ }^{7}$ Economic Community of West African States (ECOWAS), known by its French acronym, CEDEAO (Communauté Economique des Etats d'Afrique de l'Ouest)

${ }^{8}$ West African Economic and Monetary Union, known by its French acronym, UEMOA (Union Economique et Monétaire Ouest-Africaine).

${ }^{9}$ International Union for Conservation of Nature and Natural Resources

${ }^{10}$ Industrialized countries previously were interested in biofuels during the 2nd oil shock of 1979.

${ }^{11}$ Commissariat à l'énergie atomique et aux énergies alternatives.

${ }^{12}$ There also were Chinese bioethanol projects.

${ }^{13}$ For example: the regional feasibility study on setting up biomass brick factories and carbonized biomass charcoal as alternative fuel, the study of establishing a regional biomass energy data base, the study of the development of the "ethanol / gel fuel" sector for cooking fuel in the UEMOA area (UEMOA reports).

${ }^{14} \mathrm{SNV}$ is the Netherlands Development Organisation and GTZ (now GIZ) is the international cooperation agency for development (Deutsche Gesellschaft Fur Internationale Zusammenarbeit).

${ }^{15}$ The same shortfalls have been noted elsewhere in Africa. Many failures in bioenergy development and hesitation on the part of investors in most East African countries were due to the absence of policies which were realistic (acknowledge the reality of agriculture in the country), stable and targeting long-term and sustainable actions.

${ }^{16}$ For some engines, raw Jatropha oil can immediately replace diesel, for others, the engine needs to be adapted, and for yet others, the use of this fuel is impossible.

${ }^{17} \mathrm{~A}$ national confederation of farmer organizations.

${ }^{18} \mathrm{~A}$ research institute studying rural economics.

${ }^{19} \mathrm{~A}$ multifunctional platform is equipped with a diesel engine able to power different machinery, for example, a mill to grind grains, a husker, or a battery charger. The engine also can generate electricity for lighting and refrigeration and to pump water.

${ }^{20}$ European Institute for Energy Research.

${ }^{21}$ Two industrial biodiesel production units using JC oil were given to Belwetbiocarburant and Fasobiocarburant SA and an oilseed press for the production of PPO to Aprojer.

${ }^{22}$ It has been well demonstrated in France and Europe for oilseeds and in Brazil for sugar cane, two countries/ continents where biofuels have been developed, that this energy outlet saved agricultural sectors which had been struggling to remain profitable.
${ }^{23}$ Despite some scientific research findings pointing to a positive impact on food crop yields when food crops are cultivated in association with biofuel crops: studies and master's thesis supervised by Makido Ouédraogo.

\section{Abbreviations}

2iE: Institut International d'Ingénierie de l'Eau et de l'Environnement (International Institute for Water and Environmental Engineering); ABC: Brazilian Cooperation Agency; ADECIA: Agence pour le développement de la coopération internationale dans les domaines de l'agriculture, de l'alimentation et des espaces ruraux; AFD: Agence française de développement (French Development Agency); ANADEB: Agence Nationale de Développement des Biocarburants (national biofuels development agency in Mali); BNDES: Brazilian Development Bank; CEA: Commissariat à l'énergie atomique et aux énergies alternatives; CEDEAO or ECOWAS: Communauté Economique des Etats d'Afrique de l'Ouest (Economic Community of West African States); CICAFIB: Comité interministériel chargé de la coordination des activités de développement des filières biocarburants (Burkina Faso); CIRAD: Centre de Coopération Internationale en Recherche Agronomique pour le Développement; CNB: Comité national des biocarburants (Sénégal) and Commission nationale biocarburant (Mali); CNOP: Coordination nationale des organisations paysannes (Mali); CNPB: Commission nationale de promotion des biocarburants (Bénin); DDO: Distillated diesel oil; EIFER: European Institute for Energy Research; GIZ: Deutsche Gesellschaft Fur Internationale

Zusammenarbeit; IER: Institut d'Economie Rurale (Mali); IOB: Institute of Development Policy and Management; IRAM: Institut de Recherches et d'Applications des Méthodes de développement; IUCN: International Union for Conservation of Nature and Natural Resources; JC: Jatropha curcas; LOASP: Loi d'orientation agro-sylvo-pastorale (Benin); MMCE: Ministère des Mines, des Carrières et de l'Energie; MME: Ministère des Mines et de l'Energie; PPO: Pure plant oil; PRBE: Programme regional biomasse-énergie; PSRSA: Plan stratégique de relance du secteur agricole (Benin); SNV: The Netherlands Development Organisation; UEMOA: Union Economique et Monétaire Ouest-Africaine

\section{Acknowledgements}

The authors acknowledge their colleagues, Jean-Jacques Gabas, professor at University of Paris-Sud 11 and researcher at CIRAD, for supervising CG's thesis; and Joël Blin, instructor at 2iE (Institut International d'Ingénierie de I'Eau et de l'Environnement) in Ouagadougou, researcher at CIRAD, and manager of the research action on biofuels in West Africa initiated by the European Commission (2010-2014) which financed the thesis.

This publication would not have been possible without the unwavering support of Henny Romijn from the Eindhoven University of Technology, the Netherlands; and without the talent of our translator Grace Delobel. We acknowledge them.

\section{Funding}

Research Action is funded by the European Commission: Valorisation énergétique de la biomasse en Afrique de l'Ouest - volet biocarburants (2010-2014), research conducted by 2iE and CIRAD.

Appraisal study of bioenergy policies in Central and West Africa, is performed by CIRAD for IRAM (French studies center) and the Hub Rural and supported by the European Union (2014).

Availability of data and materials

Not applicable.

\section{Authors' contributions}

The main results come from the thesis of CG defended on 16 June 2015. $\mathrm{MHD}$ recruited $\mathrm{CG}$ as a PhD student and was one of the supervisors of his thesis. CG carried out all of the stakeholder surveys used in the manuscript. MHD supported CG for some surveys of political actors and for a multicriteria analysis of the potential impacts of biofuels used in order to understand the interplays among stakeholders. CG wrote the first draft of the manuscript. MHD then read the text and completed the manuscript. All authors read and approved the final manuscript. 


\section{Competing interests}

The authors declare that they have no competing interests.

\section{Consent for publication}

Not applicable.

\section{Publisher's Note}

Springer Nature remains neutral with regard to jurisdictional claims in published maps and institutional affiliations.

\section{Author details}

${ }^{1}$ University Ouaga II, BP 6309 Ouagadougou, Burkina Faso. ${ }^{2}$ UMR Actors, Resources and Territories in Development (ART-Dev) - Centre de coopération internationale en recherche agronomique pour le développement (CIRAD), 73 rue Jean-François Breton, 34398, Montpellier Cedex 5, France.

Received: 27 January 2017 Accepted: 3 April 2017

Published online: 27 April 2017

\section{References}

1. Janin P, Ouédraogo FDC (2009) Enjeux des Agrocarburants au Burkina Faso: le cas du Jatropha Curcas. IRD, Paris, p 12

2. Dabat MH, Blin J, Hanff E (2012) Are biofuels a factor of sustainable development in a food insecurity context in Africa? Case study of Burkina Faso. In: Olla P (ed) Global sustainable development and renewable energy systems. Hershey : Information Science Reference. pp 152-171

3. Tatsidjodoung P, Dabat MH, Blin J (2012) Insights into biofuel development in Burkina Faso: potential and strategies for sustainable energy policies. Renew Sustain Energy Rev 16(7):5319-5330

4. Burnod P, Gazull L, Gauthier D (2010) Les agrocarburants au Mali : nouveau produit, vieilles recettes ? Une analyse de l'émergence et des enjeux du système d'innovation agrocarburant. ISDA 2010b, Montpellier, p 20

5. Audouin S, Chapuis A, Derra S, Gatete C, Dabat MH, Gazull L (2013) Un cadre d'analyse pour évaluer les filières de production de biocarburants à base d'huiles végétales en Afrique de l'Ouest. In: Blin J, Mouras S, Wadre A, Voron A (eds) Quel bilan et quelles voies d'avenir pour les biocarburants et les bioénergies en Afrique? Sud Sciences et Technologies, Ouagadougou, pp 2-15

6. Muller $P(2009)$ Les politiques publiques. $8^{\text {ème }}$ éd. Presse Universitaire de France (PUF), Paris

7. Sabatier PA (1998) Advocacy Coalition Framework: revisions and relevance for Europe. Public Policy 5(1):98-130

8. Gatete C (2015) Perceptions et jeu d'acteurs dans la construction de l'action publique et des modes de gouvernance dans la filière agrocarburant et effets structurants potentiels sur le développement au Burkina Faso. Thèse de doctorat de l'Université Paris Sud 11 et de l'Institut International d'Ingénierie de l'Eau et de l'Environnement (2iE), Sceaux, p 540

9. Turcksin L, Macharis C, Lebeau K, Boureima F, Van Mierlo J, Bram S, Pelkmans L (2011) A multi-actor multi-criteria framework to assess the stakeholder support for different biofuel options: the case of Belgium. Energy Policy 39(1):200-214

10. Hajer M (2006) Doing discourse analysis: coalitions, practices, meaning. In: van den Brink M, Metze T (eds) Words matter in policy and planning: discourse theory and method in the social sciences. Netherlands Geographical Studies 344, Utrecht, pp 65-74

11. Favreto N, Lindsay C, Andrew J, Dougill (2012) Policy and institutional frameworks for the promotion of sustainable biofuels in Mali. Centre for Climate Change Economics and Policy Working Paper No. 103. Sustainability Research Institute Paper No. 35, Londres, p 18

12. Martin N, Rice J (2015) Improving Australia's renewable energy project policy and planning: a multiple stakeholder analysis. Energy Policy 84:128-141

13. Franzén F, Hammer M, Balfors B (2015) Institutional development for stakeholder participation in local water management-an analysis of two Swedish catchments. Land Use Policy 43:217-227

14. Jami AA, Walsh PR (2014) The role of public participation in identifying stakeholder synergies in wind power project development: the case study of Ontario, Canada. Renew Energy 68:194-202

15. Curry R, Barry J, McClenaghan A (2013) Northern Visions? Applying methodology to understand stakeholder views on the environmental and resource dimensions of sustainability. J Environ Plan Manag 56(5):624-649
16. Hauck J, Görg C, Varjopuro R, Ratamäki O, Jax K (2013) Benefits and limitations of the ecosystem services concept in environmental policy and decision making: some stakeholder perspectives. Environ Sci Pol 25:13-21

17. Luyet V, Schlaepfer R, Parlange MB, Buttler A (2012) A framework to implement stakeholder participation in environmental projects. J Environ Manag 111:213-219

18. Fraser EDG, Dougill AJ, Mabee W, Reed MS, McAlpine P (2006) Bottom up and top down: analysis of participatory processes for sustainability indicator identification as a pathway to community empowerment and sustainable environmental management. J Environ Manag 78:114-127

19. Rowe G, Frewer $L$ (2000) Public participation methods: a framework for evaluation in science. Technol Hum Values 25:3-29

20. Gabas JJ, Goulet F (2013) Les coopérations agricoles chinoises et brésiliennes en Afrique. Afrique Contemporaine 3(243):111-131

21. Rasmussen A, Toshkov D (2013) The effect of stakeholder involvement on legislative duration: consultation of external actors and legislative duration in the European Union. Eur Union Politics 14(3):366-387

22. Fraser $E$, Hubacek K (2007) The challenge of land use change: international dimensions. In: Steininger K, Cogoy M (eds) The economics of sustainable development: international perspectives. Edward Elgar, Cheltenham

23. Prukkanone K, Wang G (2016) Stakeholder analysis of environmental policymaking process in Thailand. J Public Adm Gov 6(2):100-114

24. Pinson G (2015) Gouvernance et sociologie de l'action organisée. Action publique, coordination et théorie de l'État. L'Année sociologique 65(2):483-516

25. Ecalle $F$ (2013) La coordination des politiques et des comptabilités publiques dans le cadre des engagements européens de la France. Politiques et manage public 30(3):339-349

26. Tritz Y (2012) Le Système énergétique agri-territorial: les bioénergies comme outil de développement local. Géographie Économie Société 14(1):31-52

27. Lascoumes $P$, le Galès $P$ (2012) Sociologie de l'action publique: Domaines et approches, 2èmeth edn. Armand Colin, Paris

28. Kroll JC (2007) Agriculture, fournisseurs, filières. In: Pisani E, Lebiez M (eds) Une politique mondiale pour Nourrir le monde. Springer, Paris, pp 33-47

29. Ornston D, Schulze-Cleven T (2015) Conceptualizing cooperation coordination and concertation as two logics of collective action. Comp Pol Stud 48(5):555-585

30. Dabat MH (2011) Les nouveaux investissements dans les agrocarburants. Afrique Contemporaine 237(1):97-109

31. Coase RH (1992) The institutional structure of production. Am Econ Rev 82(4):713-719

32. Williamson OE (1994) Les institutions de l'économie. InterEditions, Paris, p 404

33. Ménard C (2003) L'approche Néo-institutionnelle: Des concepts, une méthode, des résultats. Cahiers d'économie politique 1(44):103-118

34. Moustier $P$, Egg J, Tallec $F$ (2006) Coordination et qualité dans les filières agricoles du Sud Série Cahier de Recherche vol n4, p 94

35. Jia X, Bijman J (2014) Contract farming: Synthetic themes for linking farmers to demanding markets. In: Da Silva CA, Rankin M (eds.), Contract Farming for Inclusive Market Access. FAO, Rome, pp 21-38

36. Chassagnon V (2014) Beyond markets and hierarchies: an economic analysis of vertical quasi-integration. Revue de philosophie économique 15(1):135-165

37. Arinloye DDA, Hagelaar G, Linnemann AR, Pascucci S, Coulibaly O, Omta OS, Van Boekel MA (2012) Multi-governance choices by smallholder farmers in the pineapple supply chain in Benin: an application of transaction cost theory. African Journal of Business Management 6(38):10320

38. Vergriette B (2002) Contrats et concertation entre acteurs des filières vivrières. In: Synthèse des rencontres de Mbalmayo. Yaoundé 7 au 11 juillet Cameroun, Inter-Réseaux Développement rural, p 80

39. Ministère des Mines et de l'Energie (MME) 2iE CIRAD (2013) Quel bilan et quelles voies d'avenir pour les biocarburants et les bioénergies en Afrique? Collection Actes de conférences. 4ème Conférence Biocarburants Bioénergies. Éditions Sud Sciences et Technologies, p 198

40. IOB (2013) Renewable energy: access and impact. A systematic literature review of the impact on livelihoods of interventions providing access to renewable energy in developing countries. Ministry of Foreign Affairs of the Netherlands, The Hague

41. ADECIA (2013) Dynamique de production du Jatropha au Burkina Faso. Mission ARP pour I'ADECIA de janvier 2013. Rapport final, p 63

42. Muller $P$ (1990) Les politiques publiques entre secteurs et territoires. Politiques et management public 8(3):19-33

43. Wagner RE (1966) Pressure groups and political entrepreneurs: a review article. Public Choice vol 1:161-170 
44. Saurugger S, Surel Y (2006) L'européanisation comme processus de transfert de politique publique. Revue internationale de politique comparée 13(2):179-211

45. Reed MS, Graves A, Dandy N, Posthumus H, Hubacek K, Morris J, Stringer LC (2009) Who's in and why? A typology of stakeholder analysis methods for natural resource management. J Environ Manag 90(5):1933-1949

46. Thurlow J, Branca G, Felix E, Maltsoglou I, Rincón LE (2015) Producing biofuels in low-income countries: an integrated environmental and economic assessment for Tanzania. Environmental and resource economics. pp 1-19

47. Dale BE, Anderson JE, Brown RC, Csonka S, Dale VH, Herwick G, Lynd LR (2014) Take a closer look: biofuels can support environmental, economic and social goals. Environmental science \& technology 48(13):7200-7203

48. Gatete C, Dabat MH (2014) Développement des agrocarburants en Afrique de I'Ouest. Une analyse institutionnelle comparative. Économie Rurale 344:9-27

49. Arndt C, Pauw K, Thurlow J (2012) Biofuels and economic development: a computable general equilibrium analysis for Tanzania. Energy Econ 34(6):1922-1930

50. Silalertruksa T, Gheewala SH, Hünecke K, Fritsche UR (2012) Biofuels and employment effects: Implications for socio-economic development in Thailand. Biomass Bioenergy 46:409-418

51. Amigun B, Musango JK, Stafford W (2011) Biofuels and sustainability in Africa. Renew Sust Energ Rev 15(2):1360-1372

52. Sulle $E$ (2015) The biofuels boom and bust in Africa: a timely lesson for the New Alliance initiative. Future agricultures, Brighton

53. Commission Economique pour l'Afrique (CEA (2008) Biocarburants: Quelles stratégies pour le développement des biocarburants en Afrique de l'Ouest? Bureau régional Afrique de I'Ouest. CEA-AO/CIE.11/2008/4B

54. 75 UEMOA (2003) Programme régional biomasse énergie (PRBE) dans les Etats membres de I'UEMOA. La commission de I'UEMOA. Ouagadougou, p 25

55. République fédérative du Brésil and UEMOA (2007) Mémorandum d'entente entre la République fédérative du Brésil et I'Union Economique et Monétaire Ouest Africain (UEMOA) dans le domaine des biocarburants. Ouagadougou, p 5

56. Dia D, Sakho-Jimbira MS, Fall CS, Ndour A, Dieye PN (2010) Crise énergétique et recomposition de l'espace agricole au Sénégal : cultures traditionnelles vs biocarburants ? Sciences Sud et Technologies Semestriel N ${ }^{\circ} 19$ \& 20., pp 69-80

57. Gouvernement du Burkina Faso (2009) Document cadre de politique de développement des biocarburants au Burkina Faso. Ouagadougou, p 44

58. Gouvernement du Mali (2008) Stratégie nationale de développement des biocarburants. Bamako

59. Gouvernement du Mali (2011) Cadre réglementaire de développement des biocarburants. Bamako

60. Janssen R, Rutz D, Khawaja C (2013) Policies for sustainable biomass in southeast Africa. In: Blin J, Mouras S, Wadre A, Voron A (eds) Quel bilan et quelles voies d'avenir pour les biocarburants et les bioénergies en Afrique? Éditions Sud Sciences et Technologies, Ouagadougou, pp 132-141

61. Leloup F, Moyart L, Pecqueur B (2005) La gouvernance territoriale comme nouveau mode de coordination territoriale? Géographie Économie Société 7(4):321-332

62. De Vita G, Lagoke O, Adesola S (2015) Nigerian oil and gas industry local content development: a stakeholder analysis. Public Policy and Administration 31(1):51-79

63. Corral S, Legna-de la Nuez D, De Lara DRM (2015) Integrated assessment of biofuel production in arid lands: Jatropha cultivation on the island of Fuerteventura. Renew Sust Energ Rev 52:41-53

64. Schut M, van Paassen A, Leeuwis C (2013) Beyond the research-policy interface. Boundary arrangements at research-stakeholder interfaces in the policy debate on biofuel sustainability in Mozambique. Environ Sci Pol 27:91-102

65. Ministère de l'Energie du Mali (2013) Normes pour la production de bioéthanol, de biodiesel et d'huile végétale pure. Bamako

66. Dabat M-H (2011) Les nouveaux investissements dans les agrocarburants, Afrique Contemporaine, 237(1):97-109

67. Litvine D, Gazull L, Dabat MH (2014) Assessing the potential demand for biofuel by combining economics and psychology: a focus on proximity applied to Jatropha oil in Africa. Ecol Econ 100:85-95

68. Pollitt C (2003) The essential public manager. Open University Press/ McGraw, Hill Buckingham and Philadelphia
69. Bamière L, Gouel C, Martinet V (2010) Etude de la viabilité de l'approvisionnement en biomasse-énergie d'unités de transformations. Papier présenté à la Journée Economie et biocarburant du département SAE2 Paris France

70. Hanff E, Dabat MH, Blin J (2011) Are biofuels an efficient technology for generating sustainable development in oil-dependent African nations? A macroeconomic assessment of the opportunities and impacts in Burkina Faso. Renew Sustain Energy Rev 15(5):2199-2209

71. Ministère des Mines, des Carrières et de l'Energie (MMCE) (2012) Étude d'identification des opérateurs, élaboration de cahier de charge, d'un protocole de collaboration et de transfert de projets pilotes biocarburant. Rapport provisoire non publié, p 69

72. Gatete C (2013) Le sous-secteur de l'électrification rurale décentralisée (ERD) au Burkina Faso: cadre politique, approche, contraintes et analyse comparative de quatre projets. Liaison Énergie-Francophone 94:48-53

73. Dabat MH, Gautier D, Gazull L, Pinta F (2015) Energy challenges: threats or opportunities? In: Sourisseau J-M (ed) Family farming and the Worlds to come. Springer Amsterdam Pays-Bas, Dordrecht, pp 181-198

74. Gouvernement du Bénin (2011) Note sur le développement de la stratégie de promotion des biocarburants au Bénin. Programme de Fourniture de services d'Énergie (PFSE). Cotonou Bénin, p 5

75. Gouvernement du Sénégal (2011) Stratégie nationale biocarburant Sénégal, Communication présentée par le ministère des Énergies renouvelables. Conférence internationale sur les Biocarburants en Afrique. 10-12 novembre Ouagadougou, p 11

\section{Submit your manuscript to a SpringerOpen ${ }^{\circ}$ journal and benefit from:}

- Convenient online submission

- Rigorous peer review

- Immediate publication on acceptance

- Open access: articles freely available online

- High visibility within the field

- Retaining the copyright to your article

Submit your next manuscript at $>$ springeropen.com 